\title{
STRATEGY OF MSMES DEVELOPMENT IN FACING THE INDUSTRIAL ERA 4.0: IN THE ACCOUNTING PERSPECTIVE
}

\author{
Dendy Syaiful Akbar \\ Fakultas Ekonomi, Universitas Galuh Ciamis, Indonesia \\ dendysyaiful1984@gmail.com \\ Eva Faridah \\ Fakultas Ekonomi, Universitas Galuh Ciamis, Indonesia \\ vae_everal@gmail.com \\ Mohamad Apip \\ Fakultas Ekonomi, Universitas Galuh Ciamis, Indonesia \\ apip.ciamis@gmail.com \\ Roni Marsiana Suhendi \\ Fakultas Ekonomi, Universitas Galuh Ciamis, Indonesia \\ ronimarsiana@unigal.ac.id
}

\begin{abstract}
The purpose of this study is to analyze the ability of MSMEs to improve industrial competitiveness and strategies to improve industrial competitiveness in the context of facing the industrial era 4.0 in an accounting perspective. The research method uses descriptive methods that are explorative in nature. The data analysis technique uses descriptive analysis techniques, which are carried out by describing the facts of the findings and presenting them by providing sufficient understanding and explanation. The results of the study show that the MSMEs sector in Indonesia has not been able to improve competitiveness in the face of the industrial era 4.0 from an accounting perspective. Meanwhile, the strategy that can be utilized by MSMEs in facing the current digital era seen from an accounting perspective is by utilizing the Government budget for MSMEs development programs, utilizing credit facilities and empowerment from banks, and utilizing technological advances.
\end{abstract}

Keywords: MSMEs, industrial era 4.0, Accounting

\section{Introduction}

The Dewan Standar Akuntansi Keuangan-Ikatan Akuntan Indonesia (DSAK-IAI has succeeded in developing the Standard Akuntansi Keuangan (SAK) in the last 10 years, which consisted of adoption of International Financial Reporting Standards (IFRS) and the preparation and issuance of SAK Entitas Tanpa Akuntabilitas Publik (SAK ETAP). Continuing this success, DSAK-IAI starting January 1, 2018, applies special Standar Akuntansi Keuangan for Entities Mikro, Kecil, dan Menengah (SAK EMKM). Winarningsih (2009) stated that the birth of the accounting standards for Micro, Small and Medium Enterprises (MSMEs) was the answer to the public demands, especially the sector which so far needed special standards to regulate the finances of its business. Along with the rise of the digital era, there are now many accounting systems in the form of software that can be used by MSMEs to facilitate the accounting of business finance. 
A serious problem faced by MSMEs is the existence of trade liberalization, such as the enactment of the ASEAN-China Free Trade Area (ACFTA) which has been effective in 2010 and has been agreed by the Government of Indonesia in the form of an agreement. Pawitan (2012) in his research explained that with the presence of ACFTA at that time until now it threatened the existence of local products, including products produced by MSMEs in Indonesia. This condition is even more severe for MSMEs in Indonesia with the enactment of the ASEAN Economic Community (AEC) in 2015. In the free trade era, the Indonesian Government did not consider the readiness of MSMEs to be able to compete, such as product quality readiness and market readiness. Phijaisanit (2017) said that in the era of free trade entrepreneurs in ASEAN must be able to compete by mobilizing their resources efficiently.

Currently, the era faced by MSMEs in Indonesia is not only the era of free trade but now they must face the digital economic era or popular with the term industrial era 4.0. Until now all residents in the world can see the effects of the internet, including the effects on the business world. The outbreak of this digital era in the business world can be felt in Indonesia, for example when the Gojek and Grab applications become a solution to congestion in big cities, with convenient services and low costs. Another example is an online business that is popular among Indonesians, where it can be carried out anywhere and anytime. Actually, there are many more examples of the impact of the digital era on the business world, but how do people today respond to that era to be more useful.

Based on these conditions, the purpose of this study is to analyze the ability of MSMEs and MSME strategies to improve industrial competitiveness in the context of facing the industrial era 4.0 in an accounting perspective.

\section{Method}

This research uses descriptive exploratory methods to analyze the development of MSMEs in the face of the industrial era 4.0 from an accounting perspective. This scientific work was developed with a literature review or literature study approach. The theory/concept approach is carried out by referring to several sources, such as scientific journals, books, and the internet. All ideas found are combined in one arrangement of thought frames.

The type of data used is secondary data, where the data collection technique is carried out by means of literature studies, namely collecting data relating to the topic of research. Literature studies can be obtained from various sources, such as journals, books, and the 
internet. Meanwhile, the data analysis technique is to use descriptive analysis techniques, which are carried out by describing the facts of the findings and presenting them by providing sufficient understanding and explanation.

\section{Result and Discussion}

The ability of MSMEs to increase competitiveness can be seen from the following components: 1) Capital; 2) Human Resources (HR); 3) Law, and; 4) Accountability. The following are the results of a literature study to describe the ability of MSMEs to improve competitiveness based on these components seen from accounting perceptions:

\section{Capital}

At present more than 55\% of MSMEs still do not have access or financing from banks. In addition to geographical location, because of the large number of MSMEs in remote and remote areas that have not been reached by banks, the main problem is administrative problems. MSME business management still runs manually, especially financial management, where most MSMEs are still unable to separate business finance and personal finances, causing unclear financial conditions of the company.

\section{Human Resources (HR)}

Most MSMEs do not understand the importance of accounting in the business world, so they still think that compiling financial reports that are in accordance with standards is an unimportant and difficult thing to do. Educational background factors are the main cause of MSME actors not applying accounting standards in preparing their business financial statements.

3. Law

The absence of regulations requires MSMEs to apply accounting standards generally accepted in Indonesia. SAK EMKM issued by the Ikatan Akuntan Indonesia (IAI) is only limited to guidelines or guidelines in the preparation of financial statements for MSMEs. This condition is different from companies that have gone public, where regulators require entities to implement IFRSs that are generally accepted in Indonesia, with the aim of protecting investors from possible investment risks.

\section{Accountability}

In terms of accountability, MSMEs do not have significant accountability to the public. This condition is due to the fact that MSMEs are still a form of individual business which 
is managed by the owner so that it does not have significant responsibility for external parties of the company. This condition is the reason why MSMEs do not feel the need to make reliable financial reports.

Based on the results of the study, it can be concluded that MSMEs in Indonesia have not been able to increase competitiveness in the context of facing the industrial era 4.0 seen from accounting perceptions. The results of this study show that a strategy is needed so that MSMEs in Indonesia can improve competitiveness in the face of the current digital era seen from accounting perceptions. The share of MSMEs for the Indonesian economy has no doubt its role. MSMEs have a very high employment rate, which is $90 \%$ more than all national labor and has a contribution to Gross Domestic Product, which is 55\% more. However, the problem faced by MSMEs is the low competitiveness in facing the free market and what is happening now is the industrial era 4.0.

In the face of the digital era, as it is today, MSMEs in Indonesia must have a strategy to increase competitiveness, so as not to be eroded by increasingly rapid technological developments. Of course, there are many gaps that can be utilized by MSME players to be able to compete in this era, such as utilizing facilities or programs from the government and other stakeholders. The following are the results of a literature study to describe the strategies for developing MSMEs to improve competitiveness in the context of facing the industrial era 4.0 which is viewed from an accounting perspective: 1) Utilization of Government Budgets; 2) Use of Banking Facilities, and; 3) Use of Technology.

Currently, in Indonesia, the accounting standards generally accepted for MSMEs are SAK EMKM. This standard is a guideline in the preparation and presentation of MSMEs financial statements and prepared by the IAI through the DSAK and applied for its implementation on January 1, 2018. With the issuance of the SAK EMKM, it is hoped that it can be an encouragement for MSMEs players in Indonesia to increase their business competitiveness. The preparation and presentation of structured and systematic financial statements are very necessary for business entities to balance financial position so that the actual financial condition of the business will be described. The financial information contained in financial statements can be used as a basis for strategic decision making for companies in the future. One effort to increase competitiveness, MSMEs require SAK ETAP as a guideline in the preparation and presentation of financial statements. 
In this industrial era 4.0, MSMEs actors must master technology and information to be able to avoid lagging and be able to compete in the era of industrial revolution. Without mastery of technology, the MSMEs sector will lag far behind in the world economy. One of the efforts to improve competitiveness in the current era is the ability of MSMEs in preparing and presenting financial statements in accordance with generally accepted standards. At present, there are several mobile-based Accounting Information System (AIS) applications that can be utilized by MSMEs actors as a means to facilitate the preparation of financial statements. However, the existence of these applications must be balanced with the ability of MSMEs in understanding accounting, so as not to misread the output produced by the SIA application based on the mobile phone.

The development of AIS for mobile phone-based MSMEs is seen as feasible and important because accounting information systems are adding value to the company. AIS can provide added value by a) provide accurate and timely information, b) the application of accounting information systems increases the effectiveness and cost efficiency in collecting economic information, c) help and improve the quality of decisions that will be taken by management, d) increase knowledge sharing (Fauzi, 2017).

In the accounting perspective, the ability of MSMEs in Indonesia to increase competitiveness in the face of the industrial era 4.0 can be seen from several factors. The first is capital, Susilo (2010) said that one of the problems of MSMEs was in terms of capital because it was difficult to get access to banking. This is due to inadequate management of MSME finance in Indonesia, especially financial management because one of the requirements for applying for bank credit is the attachment of business financial statements. The financial statements presented by MSME actors have not met accounting standards relevant to the MSME sector, one of which is that they have not applied the entity concept. The concept requires business finance to be separated from his personal finances.

The concept of business entity (entity concept) indicates that a business entity must be seen as a stand-alone entity, acting in its own name and separate from investors, creditors and other external parties (Sari, 2013). The statement explains that the business entity is independent and separate from other parties, including separate from the owner. In most MSMEs, this does not apply, because MSMEs are managed by their own owners, so the owner thinks that the company's finances are his personality. 
Most MSMEs do not separate business finance from their personal finances. This condition causes the information generated from the records made by MSMEs actors not to reflect the actual financial condition of the business. If MSMEs can access capital from banks, then the additional capital can be used as an investment tool in business development. Waworuntu, Rotinsulu, \& Mandeij (2017) in their research stated that increasing credit or financing from banks to MSMEs was needed to strengthen the role of MSMEs in the structure of the national economy.

The second is Human Resources (HR). The problem faced by MSMEs related to the preparation and presentation of business financial statements is the lack of skilled labor in the field of accounting (Wuwungan, 2015). In most MSMEs in Indonesia, they have not been able to compile and present adequate financial reports, where they only carry out simple and simple bookkeeping. Factors of human resources that do not have a basic accounting which is one source of causes of MSMEs have not been able to do adequate accounting. The average MSMEs actor does not have the basic accounting obtained in his formal education. In addition, MSMEs actors have limited time to practice and study accounting. Time is one of the factors taken into account by MSMEs actors, where they think that preparing financial statements will take a long time and will ignore the main activities of their business.

These conditions can be overcome by the existence of accounting applications in the form of software. The application was made to facilitate the accounting of business finance. But the existence of these applications will be useless if the user does not understand the information contained in the financial statements generated from the application process. Even if you have to recruit employees to handle business finance bookkeeping, MSMEs players will think that the company's burden will increase.

Thus improving the quality of human resources in a business entity is very necessary for the context of business development and can increase profits. One of the human resources needed in the MSME sector is accounting human resources so that there are parties who can handle the financial management of their business. Berk, Bertsimas, Weinstein, \& Yan (2018) argue that the Human Resource (HR) design model aims to maximize profits.

The third is the law. There is no rule that requires MSMEs to apply accounting standards that apply to Indonesia. This condition is the reason why MSMEs do not prepare and present accounting with applicable accounting standards and are relevant to their business clusters. According to Neag \& Maşca (2012) accounting standards for small businesses are 
believed to be able to become a business strategy in the future. The statement explained that the accounting standards for the MSME sector in agriculture were important for business development in the sector in the face of uncertainty in the future era. Meanwhile, Zager \& Decman (2016) argues that accounting standards for micro-enterprises can be used as a solution to assist the financial accounting of micro sector businesses.

The fourth is accountability. Insignificant public accountability is another cause in the low use of accounting standards in the preparation and presentation of financial statements for MSMEs in Indonesia. MSMEs are generally family businesses managed by their owners so that MSMEs are not obliged to present financial reports to external parties of the company. According to Narsa, Widodo, \& Kurnianto (2012) in his research, MSMEs only carry out simple and simple financial records and are done manually using notebooks. The reason MSMEs actors do not present financial reports that are in accordance with accounting standards is that they make reports only for themselves.

Such conditions show that the MSME sector has not been able to compete in the industrial era 4.0 seen from an accounting perspective. For this reason, a strategy is needed so that MSMEs can compete in the current digital era. There are several strategies carried out by MSMEs to be able to compete in the current era. The first strategy is the utilization of the Government Budget. Until now, the Indonesian Government has spent a lot of budgets to finance development programs and empowerment of MSMEs. The budget is used to finance the development and empowerment of MSME programs, whether carried out by the Government itself or through research institutions in the form of training, socialization, partnerships, research, and Community Service Program (PKM). One form of the development program is in the field of accounting, with the aim that MSMEs have financial accounting in accordance with applicable accounting standards in Indonesia in the form of SAK EMKM.

SAK EMKM is new standards compiled by IAI. Aimed at MSMEs, standards are arranged more simply. By compiling reports according to the EMKM SAK, MSMEs can submit funding from other parties as well as a basis for tax reporting (Winarningsih, 2009). At present many accounting applications in the form of software or mobile-based accounting applications can be used by MSME actors to facilitate the preparation and presentation of financial statements. However, MSMEs must first understand the relevant accounting 
standards applied to the MSMEs sector, so that MSME actors understand the information contained in financial statements.

The second strategy is the use of banking facilities. Banking in Indonesia through Government policy through Bank Indonesia provides credit facilities to assist MSMEs capital. With the existence of these facilities, MSMEs must use them for investment activities in order to develop their business. According to Nisa (2016), the banking credit policy proved to be significant towards the increase of MSMEs in Indonesia.

At present Bank, Indonesia has also provided guidance and various activities to empower MSMEs in the form of a Bank Partner Financial Consultant program. This program aims to provide managerial assistance, one of which is financial management of MSMEs. Financial management is the process of managing business finance to produce financial information that can be utilized by internal parties in the context of decision making. Of course, this program is very beneficial for MSMEs in order to be able to compile and present structured and systematic financial reports.

The third strategy is the use of technology. In an industry, specific internal processes and procedures are needed, including the support of information technology resources, to facilitate the transfer of information to each stakeholder (Jean et al, 2014). The statement explained that information technology played a major role in business development, including the MSMEs sector. Information generated from all business processes, including company financial information is needed in strategic decision making in the future.

In today's digital era, many accounting applications have emerged in the form of software. The application helps facilitate the preparation of business financial statements. MSMEs as one of the business sectors can utilize these technologies to be able to compete because they have adequate financial reports. Otherwise, the MSMEs sector in Indonesia will be eroded in the digital era today. The existence of an accounting application can facilitate MSMEs in managing various financial resources in the relevant MSMEs, to be more effective, efficient (Lestiawan \& Mahmud, 2014).

\section{Conclusion}

Based on the results and discussion, it can be concluded that MSMEs in Indonesia have not been able to improve competitiveness in the face of the industrial era 4.0 seen from an accounting perspective. This condition was caused by a difficult capital problem to access 
bank credit because the financial accounting conditions of MSMEs did not yet meet the category in the bank loan application requirements. Next, the quality of MSME human resources in the preparation and presentation of financial statements is still low. Meanwhile, from a legal standpoint, there are no rules that require MSMEs to present financial reports that comply with accounting standards applicable in Indonesia. Furthermore, MSMEs do not have significant accountability to the public, which means that MSME actors do not need to present adequate financial reports.

For this reason, a strategy that can be used by MSMEs is needed to compete in today's digital era. One of the strategies is to utilize the Government budget to finance MSMEs development programs, one of which is financial management training. The next strategy is to utilize banking facilities, where facilities provided by banks for the MSMEs sector in Indonesia are business capital credit facilities and MSMEs empowerment programs. Another strategy is to utilize technological advancements, including the emergence of accounting applications in the form of software. The application can facilitate the preparation and presentation of MSMEs financial statements.

This study has limitations that can be done by future researchers in the future. These limitations, such as the method used by literature review or literature study, where data only comes from journals, books, and the internet. For the next study, it is recommended that the data must be searched from the source directly so that it will add information that is truly valid. In addition, the strategies taken are suggested to use SWOT analysis techniques, so that we can know the weight of each strategy based on its priority scale.

\section{Reference}

Berk, L., Bertsimas, D., Weinstein, A. M., \& Yan, J. (2018). Prescriptive Analytics for Human Resource Planning in the Professional Services Industry. European Journal of Operational Research. https://doi.org/10.1016/j.ejor.2018.06.035

Fauzi, R. A. (2017). Sistem Informasi Akuntansi Berbasis Mobile Bagi UMKM. Seminar Nasional Riset Inovatif, 3. Retrieved from https://books.google.co.id/books?id=sf4wDwAAQBAJ\&printsec=frontcover\&dq=Karak teristik+Sistem+Menurut+Fauzi+2017\&hl=id\&sa=X\&ved=0ahUKEwjvlJ-f2-

3aAhVFso8KHQCaAWIQ6AEIQDAF\# $\mathrm{v}=$ onepage \&q\&f=false

Lestiawan, H., \& Mahmud. (2014). Purwarupa Pembelajaran Mandiri Sistem Aplikasi Akuntansi UMKM Berbasis Web Dalam Pemberdayaan Usaha Masyarakat Jawa Tengah. Prosiding Snatif, (2005), 445-452.

Narsa, I. M., Widodo, A., \& Kurnianto, S. (2012). Mengungkap Kesiapan Umkm Dalam Implementasi Standar Akuntansi Keuangan Entitas Tanpa Akuntabilitas Publik (Psak- 
Etap) Untuk Meningkatkan Akses Modal Perbankan. Majalah Ekonomi, (3), 204-214. https://doi.org/10.20473/JEBA.V22I32012.4308

Neag, R., \& Maşca, E. (2012). Determinants in Accounting Regulation for Micro-Entities-a Romanian Perspective. Procedia Economics and Finance, 3(12), 223-229. https://doi.org/10.1016/S2212-5671(12)00144-X

Nisa, C. (2016). Analisis Dampak Kebijakan Penyaluran Kredit Kepada Umkm Terhadap Pertumbuhan Pembiayaan Umkm Oleh Perbankan. DeReMa Jurnal Manajemen, 11(2), 212-234. https://doi.org/10.19166/derema.v11i2.231

Pawitan, G. (2012). Characteristics of Small Medium Manufacturing Industries In the Era of ACFTA : case study from West Java. Prcedia Economics and Finance, 4(Icsmed), 130139. https://doi.org/10.1016/S2212-5671(12)00328-0

Phijaisanit, E. (2017). AEC and the Changing Economic Landscape. Internationalization and Managing Networks in the Asia Pacific. Elsevier Ltd. https://doi.org/10.1016/B978-0-08100813-3.00002-X

Sari, D. P. (2013). Telisik Perlakuan Teori Entitas Usaha Mikro, Kecil dan Menengah. Jurnal Akuntansi Multiparadigma, 4, 165-329.

Susilo, Y. S. (2010). Di Provinsi Diy. Jurnal Keuangan Dan Perbankan, 14(3), 467-478.

Waworuntu, M., Rotinsulu, T. O., \& Mandeij, D. (2017). Peran Sektor Perbankan Dalam Mengembangkan Daya Saing Usaha Mikro Kecil Dan Menengah (UMKM) Margareta Waworuntu Kriteria UMKM No Usaha Kriteria Asset Omzet 1 . Usaha Mikro Sumber : Kementerian Koperasi Usaha Kecil dan Menengah , 2012 Margareta Waworuntu. Efisiensi, 17(1), 183-193.

Winarningsih, S. (2009). Sosialisasi standar Akuntansi Keuangan Untuk UMKM. Www.feb.unpad.ac.id/dokumen/file, 1-24. $\quad$ Retrieved from http://www.feb.unpad.ac.id/dokumen/files/Sosialisasi-standar-akuntansi-keuanganuntuk-UMKM_Srihadi.pdf

Wuwungan, J. Y. S. (2015). Analisis Penerapan Standar Akuntansi Keuangan Entitas Tanpa Akuntabilitas Publik Atas Persediaan Pada Apotik Uno Medika. Jurnal EMBA, 3(4), 498-507.

Zager, K., \& Decman, N. (2016). Guidelines and Recommendations for Improving the Micro Entities Model of Financial Reporting. Procedia Economics and Finance, 39(November 2015), 451-457. https://doi.org/10.1016/S2212-5671(16)30348-3 